\title{
EL PROCESO DE FORMALIZACIÓN SEMÁNTICA EN TARSKI Y EN CARNAP
}

Los intentos de formalización de la semántica del lenguaje se remontan a Lesniewski, según referencia de Tarski, pero es en realidad éste quien inicia la tarea de construir una estructura lógica del lenguaje que contenga y defina conceptos tales como 'verdad', 'significación', 'sinonimia', 'implicación' et alia. ${ }^{1}$ El primer paso en la investigación llevada a cabo por Tarski para lograr una base de formalización del lenguaje consistió en estudiar las posibilidades de estructuración lógica del lenguaje ordinario ("colloquial language") y consiguiente definición de sus términos. Los resultados a que llega Tarski en esta vía son totalmente negativos: no sólo descubre que no es posible la formalización del lenguaje cotidiano, sino que ni siquiera tiene sentido plantear rigurosamente en dicho lenguaje el problema de la coherencia o no coherencia de sus expresiones. Una posición tan rigida, además de estar de acuerdo con la filosofía dominante en el Círculo de Viena, marcó durante un tiempo la línea de interpretación de problemas afines, por lo que nada tiene de extraño que el Carnap de The Logical Syntax of Language asumiera posiciones similares a las de Tarski. Sin embargo, prima facie la diferencia entre las tesis de Tarski y las de Carnap acerca del lenguaje natural y de su posibilidad o imposibilidad de tratamiento semántico formalizado se establece con cierta precisión respecto del concepto 'verdad' y su pretendida definición semántica. El rastreo y desarrollo de semejante diferencia pone de manifiesto el cambio que, posteriormente, se operó en el Carnap de Introduction to Semantics y, más decididamente, en el de Meaning and Necessity.

El punto central que resume la tesis original de Tarski, enteramente negativa, acerca del lenguaje natural viene dado en The concept of truth in formalized languages:

(...) coloquial language is the object of our investigations. The results are entirely negative. With respect to this language not only does the

1 Las obras fundamentales de Tarski sobre este punto son: "Der Wahrheitsbegriff in den formalisierten Sprachen" (Studia Philosophica, 1, 1935), traducida al inglés como: "The concept of truth in formalized languages" (in: Logic, Semantics and Metamathematics, Oxford, 1956); "Grundlagen der wissenschaftlichen Semantik" (Actes du Congrès International de Philosophie Scientifique, Paris, 3, 1936), traducido en Logic, Semantics...; "The semantic conception of truth and the foundations of semantics" (Philosophy and Phenomenological Research, 4, 1944), reproducido en: H. Feigl-W. Sellars, Readings in philosophical Analysis (New York, 194.9) y en L. Linsky: Semantics and the Philosophy of Language (Urbana, 1952) y traducido al español en: M. Bunge, Antologia Semántica (Buenos. Aires, 1960). 
definition of truth seem to be impossible, but even the consistent use of this concept in conformity with the laws of logic. ${ }^{2}$

Lo que explica y justifica la imposibilidad aludida es el hecho de la formación de paradojas lógicas (tipo antinomia del mentiroso) a partir de la introducción de esquemas orientadores para definir el concepto de verdad en lenguaje natural, tales como: ' $X$ es una proposición verdadera si y sólo si $p$ ' (donde se toma a ' $\mathrm{X}$ ' como nombre que designa a una proposición y a ' $\mathrm{p}$ ' como variable de proposición). La conclusión general de Tarski apunta hacia la imposibilidad de especificar "estructuralmente" (esto es, mediante un proceso de formalización) cuáles expresiones del lenguaje corriente merecen ser clasificadas como proposiciones; por lo cual, a fortiori, no se pueden distinguir las proposiciones verdaderas de las que no lo son. ¿Significa esto que todo intento de formalizar términos de valor semántico en el lenguaje coloquial está definitivamente condenado el fracaso señalado por Tarski? No necesariamente, como el mismo Tarski reconoce; ${ }^{3}$ pues, si pese a tales dificultades, se quisiera persistir en el empeño de establecer una semántica "natural", habría que proceder mediante el recurso heroico de la reforma del lenguaje, csto es, llegar a definir su estructura para superar la ambigüedad de los términos en él empleados. Por último, sería menester romper el lenguaje natural en una serie de lenguajes de extensión creciente con respecto al anterior a fin de que, entre sí, quedasen en la misma relación que existe entre un lenguaje formalizado y su metalenguaje:

It may, however, be doubted whether the language of everyday life, after being 'rationalized' in this way, would still preserve its naturalness and whether it would not rather take on the characteristic features of the formalized languages. ${ }^{4}$

Si en la obra citada, Tarski se limita a constatar la imposibilidad de formalización del lenguaje natural (reservando la mayor parte de la investigación a los lenguajes de suyo formalizados: cálculo de clases, por ejemplo), en cambio en Grundlegung der wissenschaftlichen Semantik explica el porqué de aquella imposibilidad. Sucede que los conceptos semánticos que tradicionalmente han desempeñado un papel destacado en las discusiones filosóficas y, muy particularmente, el concepto de 'verdad', poseen un carácter relativo, es decir, para su comprensión siempre es necesario referirlos a un determinado lenguaje. Lo que significa que hay que partir del supuesto según el cual el lenguaje acerca del cual se habla no necesariamente ha de coincidir con el lenguaje en el que se habla. Intentar describir la semántica

\footnotetext{
2 Logic, Semantics, Metamathematics (ed. cit.), p. 153 .

3 Loc. cit., pp. $164,267$.

4 Loc. cit., p. 268.
} 
de cualquier lenguaje en ese mismo lenguaje es imposible. Sólo puede alcanzarse una descripción de términos lingüísticos, en forma clara y precisa, mediante el empleo de términos de metalenguaje que hagan referencia a la forma y disposición de signos y expresiones complejas del lenguaje del que se parte o lenguaje-objeto. En eso consistirá, entonces, la formalización de un lenguaje. Como ello obliga, de ser aceptado, a distinguir entre niveles lingüisticos, por una parte, y a utilizar, por otra, de cierta manera, en uno de esos niveles los términos que corresponden al nivel inferior, será necesario determinar las condiciones que permitan tanto la separación de niveles como el uso codificado de términos de un lenguaje en otro. Sólo así admitirá Tarski 5 el empleo de conceptos semánticos "as materially adequate".

El programa de trabajo de Tarski se llevó a cabo a partir de un concepto de primera importancia semántica: concepto de 'verdad', referido a lenguajes formalizados de orden finito o infinito, con la diferencia entre ambos de que si bien en el primer caso es posible establecer axiomáticamente los límites y propiedades del lenguaje en cuestión, en cambio, para el caso de lenguajes infinitos habría que contentarse con introducir el término 'verdad' en tanto postulado y derivar de él las expresiones que lo contengan y que se presenten en tanto teoremas del sistema, del que en todo caso no se puede probar su completitud.

Sobre el modelo del tratamiento formalizado del concepto 'verdad', propone Tarski la extensión del método a conceptos análogos. Para cada uno de los términos semánticos semejantes ('satisfacción', 'consecuencia', 'designación' y otros) habría que empezar por formular un sistema de enunciados, que se presentarian en forma de equivalencias, y que tendrian el carácter de definiciones parciales. Con esto, no sólo se alcanzaría la determinación extensiva del concepto, sino que se obtendría también su correspondiente comprensión, pues esos mismos enunciados sirven para precisar el 'sentido' (sense) respecto de todas la expresiones concretas del lenguaje estructuralmente descrito.

Tarski considera esta tarea como preliminar a la fundamentación de la semántica. Esto es: a menos que no se creen las condiciones legales para el manejo de ciertos términos a través de un metalenguaje, no será posible desarrollar la estructura formal de aquella parte del lenguaje que tiene una referencia objetiva.

Ahora bien, semejantes tareas apenas si tienen función propedéutica a la fundamentación de la semántica, que en tanto tarea a ejecutar presenta una doble posibilidad de realización. Tarski adelanta dos procedimientos constructivos para la edificación de la semántica, de los cuales preferirá, en definitiva, el segundo, una vez que ha indicado las principales desventajas del primero; éste no es otro sino el recurso de axiomatización de aquellos

5 Loc. cit., p. 404 . 
conceptos semánticos introducidos en el metalenguaje en tanto conceptos primitivos. Es innegable que, si se procede así,

semantics becomes an independent deductive theory based upon the morphology of language. ${ }^{6}$

Pero semejante solución no deja de presentar inconvenientes de cierta importancia; ante todo, el problema de la selección de los axiomas, sometido de facto a la arbitrariedad derivada de las limitaciones del conocimiento, pero muy especialmente, se presenta el riesgo de incoherencia del sistema que se pretende construir:

The problem of consistency arises, of course, whenever the axiomatic method is applied, but here it acquires a special importance, as we see from the sad experiences we have had with the semantical concepts in colloquial language. ${ }^{7}$

Desde un punto de vista estrictamente epistemológico, revélase además otra dificultad. Considera Tarski que resultaría difícil armonizar semejante procedimiento de axiomatización con los postulados de unificación de la ciencia y del fisicalismo, y ello por el hecho de que los conceptos de la semántica, así constituida, no entrarían en ninguno de los órdenes científicos admitidos, por no tratarse ni de conceptos lógicos ni de conceptos físicos. Independientemente de la referencia histórica que semejante observación contiene, cuyo valor quedaría limitado por los alcances de la tesis neopositivista, la crítica de Tarski en este punto presenta un determinado interés: permite, en definitiva, comprender un punto fundamental de su posición frente al problema de la constitución de una nueva disciplina, a partir de conceptos semánticos. De hecho, Tarski no considera a los conceptos semánticos como conceptos puramente lógicos, esto es, similares en naturaleza a los conceptos de 'congruencia' o de 'función proposicional', sino como conceptos potencialmente lógicos. Tan sólo una vez axiomatizados (por procedimiento estructural) alcanzan el status de auténticos conceptos lógicos, pero semejante condición relativa no queda compensada por alguna posible atribución de condición científica a tales conceptos desde el momento en que su interpretación no es teóricamente unívoca. Tales deficiencias muestran una posición "pesimista" de Tarski acerca de la "naturaleza" de los conceptos semánticos, que sirve bien para esclarecer, por una parte, su rechazo de cualquier intento de organización coherente de una semántica natural (coloquial) y, por otra, sus esfuerzos por elevar el contenido de la semántica a niveles de orden lógico formalizado que, en definitiva, sirvan para conferir

6 Loc. cit., p. $4^{05}$.

7 Loc. cit., pp. 404-405. 
la propiedad de disciplina científica. A fin de escapar al conjunto de dificultades encontradas en el primero de los procedimientos apuntados, se lanza la segunda proposición operativa:

In the second procedure (...) the semantical concepts are defined in terms of the usual concepts of the metalanguage and are thus reduced to purely logical concepts, the concepts of the language being investigated and the specific concepts of the morphology of language. ${ }^{8}$

Se prefigura la solución del primer Carnap a favor del exagerado logicismo (sintáctico) del tratamiento de los conceptos semánticos. En el contexto manejado, sin embargo, Tarski alude en realidad a soluciones lógicas análogas ya establecidas, como la teoría de los tipos. A partir de semejante modelo se lanza la condición de operación metodológica que, posteriormente, le servirá a Carnap de orientación en el desarrollo de una sintaxis lógica del lenguaje:

It is possible to construct in the metalanguage methodologically correct and materially adequate definitions of the semantical concepts if and only if the metalanguage is equipped with variables of higher logical type than all the variables of the language which is the subject of investigation. ${ }^{9}$

En el último trabajo especifico de Tarski sobre el tema, esto es, en The semantic conception of truth, posterior en aproximadamente un decenio al antes comentado, no hay variaciones mayores respecto del programa de establecimiento de una semántica del lenguaje formalizado. Allí, al analizar los presupuestos que conducen a la formulación de la antinomia del mentiroso, establece Tarski el concepto metodológico de 'lenguaje semánticamente cerrado' (semantically closed), que es el que permite técnicamente la construcción de paradojas. Por el contrario, en un lenguaje semánticamente "abierto" o debidamente formalizado y nivelado, no hay tal peligro porque o bien no contiene conceptos semánticos o bien los utiliza en condiciones tales de formalización y distinción de niveles que, con ello, se impide la incoherencia. Pero, en cualquier caso, Tarski no ha abandonado su animadversión metodológica hacia el lenguaje coloquial, que es el que realmente continúa presentando la mayor carga de problemas, por cuanto en él el uso de términos semánticos (sobre todo, 'verdad') trae como consecuencia la formación: de paradojas y expresiones de ambiguo sentido lógico. Seria, no obstante, un error calificar de incoherente a tal lenguaje por el solo hecho de dar lugar a la aparición de las tradicionales paradojas. La tesis de Tarski sobre este

8 Loc cit., p. 406.

9 Ibid. 
punto continúa siendo reductiva del valor lógico del lenguaje ordinario; la sola calificación de "incoherencia" equivaldría, en efecto, a una concesión lógica por cuanto dicha condición sólo es alcanzada por un lenguaje formalizado hasta el grado de la axiomatización estructural.

At first blush, it would seem that this language [el coloquial] satisfies both assumptions I and II [se refiere a las que caracterizan a un lenguaje como "semánticamente cerrado"], ${ }^{10}$ and that therefore it must be inconsistent. But actually the case is not so simple. Our everyday language is certainly not one with an exactly specified structure. We do not know precisely which expressions are sentences, and we know even to a smaller degree which sentences are to be taken as assertible. Thus the problem of consistency has no exact meaning with respect to this language. We may at best only risk to guess that a language whose structure has been exactly specified and which resembles our everyday language as closely as possible would be inconsistent. ${ }^{11}$

Conviene observar que bien pudiera derivarse de semejante constatación una línea de valoración del lenguaje coloquial distinta de la que el propio Tarski obtiene. Para Tarski, en consecuencia, un lenguaje en el que no tenga sentido hablar del sentido de dicho lenguaje (puesto que no puede ser formulado como coherente o incoherente) es un lenguaje no formalizable por vía semántica. También puede llegarse a la conclusión de que se trata de un lenguaje cuyo sentido no viene dado por las reglas lógicas de la coherencia estructural, sin que quiera ello decir que no posea sentido atribuible en sus expresiones semánticas o, por lo menos, que éstas sean definibles en el contexto del mismo.

Ciertamente que para fines de una formalización total, el resultado es el mismo, ya que la prevención de Tarski hacia dicho lenguaje lo es tan sólo del orden de la formulación condicional (si hay lenguaje en tales y cuales condiciones y si ese lenguaje es el lenguaje cotidiano, éste es incoherente). Pero si es incoherente, no es posible trabajar en él lógicamente (contra el segundo de los presupuestos fundamentales).

En resumidas cuentas, si Tarski plantea de paso el problema del sentido - no-sentido de la aplicación de la propiedad de coherencia al lenguaje coloquial, es para referirlo de inmediato al modelo de un lenguaje lógico.

10 De los dos presupuestos, el primero establece la condición general de lenguaje 'semánticamente cerrado': "We have implicitly assumed that the language in which the antinomy is constructed contains, in addition to its expressions, also the names of these expressions, as well as semantic terms such as the term 'true' referring to sentences of this language; we have also assumed that all sentences which determine the adequate usage of this term can be asserted in the language. A language with these properties will be called 'semantically closed'," mientras que el segundo encierra convencionalmente al lenguaje cotidiano en el dominio lógico: "we have assumed that in this language the ordinary laws of logic hold" (Op. cit. in: Feigl-Sellars, Readings in Philosophical Analysis, p. 59).

11 Loc. cit., p. 60. 
O no tiene sentido hablar de coherencia (problema abierto) o tiene sentido hacerlo, en cuyo caso el problema se traslada al campo de la formalización por vía de definición de conceptos semánticos y distinción de niveles lingüísticos, ya que el procedimiento para eliminar la incoherencia de un lenguaje sigue siendo para Tarski el mismo: separar lenguaje-objeto de metalenguaje.

En definitiva, a todo lo más que llega Tarski en su tarea de fundamentación de la semántica, es a: $I$ ) establecer las bases de formulación de una teoria semántica a partir de la formalización de un concepto semántico tradicional ('verdad') y de la analogización de éste con otros ('consecuencia', 'sinonimia', 'satisfacción', 'significado'); 2) negar la posibilidad de construcción de una semántica científica, específica de lenguajes no formalizados y 3) admitir la posibilidad de desarrollo de una semántica general que se pueda aplicar, una vez establecida, a una amplia y comprensiva clase de lenguajes-objeto.

Ello será. la tarea propia y más ampliada de Carnap.

Coetáneas de las tesis anti-naturalistas de Tarski en el análisis del lenguaje, las de Carnap son expuestas en The Logical Syntax of Language con no menos rigor, que se extiende incluso a la negación tajante de la posibilidad de construcción de la semántica, por carente de objeto propio. La diferencia formal mayor entre Tarski y Carnap viene dada por los cambios sucesivos del último respecto de los temas semánticos; mientras que Tarski mantiene una posición irreductible sobre la posible semántica del lenguaje no formalizado, Carnap registra toda una serie de variaciones en su obra ${ }^{12}$ que van desde el rechazo definitivo de los primeros escritos sobre el problema

12 Para los temas aquí tratados, los trabajos de Carnap relativos a ellos se sitúan cronológicamente así: Logische Syntax der Sprache (WVien, 1934), trad. al inglés como: The Logical Syntax of Language (London, 1937); Philosophy and Logical Syntax (London, 1935), trad. al español como: Filosofia y sintaxis lógica (Centro de Estudios Filosóficos, U.N.A.M., México, 1963); "Wahrheit und Bewährung" (in: Actes du Congrès International de Philosophie Scientifique, Sorbonne, Paris, 1935, 4. Induction et probabilité, Paris, 1936), adaptado al inglés como: "Truth and Confirmation" (in: Readings in Philo. sophical Analysis, ed. cit.); "Testability and Meaning" (in: Philosophy of Science, vol. 3, $\mathrm{n}^{Q}$ 4; vol. 4, $\mathrm{n}^{\odot}$, , Baltimore, $193^{6-37}$ ), editado como libro con algunos agregados y el mismo título (New Haven, Conn., 1950) y reproducido parcialmente en los Readings in the Philosophy of Science, editados por Feigl-Brodbeck (New York, 1953); Foundations of Logic and Mathematics (Chicago, 1939); Introduction to Semantics (Studies in Semantics, vol. 1, Cambridge, Mass., 1942); Formalization of Logic (Studies in Semantics, vol. 2, Cambridge, Mass., 1943); Meaning and Necessity: A Study in Semantics and Modal Logic (Studies in Semantics, vol. 3, Chicago, 1947); "Empiricism, Semantics and Ontology" (in: Revue Internationale de Philosophie, no 11, Bruxelles, 1950), incluido, como apéndice, en Meaning and Necessity, a partir de la segunda edición; Logical Foundations of Prabability (Chicago, 1950); "Meaning and Synonymy in Natural Languages" (in: Philosophical Studies, vol. 6, no 3, Minneapolis, 1955), también incorporado en Meaning and Necessity, a partir de la segunda edición. 
hasta el reconocimiento parcial del análisis del lenguaje ordinario y la formación de teorías de la extensión y la intensión para la clasificación de sus términos.

La primera muestra de la posición extrema anti-naturalista está representada por una declaración que delimita el campo de los objetos lógicos:

Questions about something which is not formally representable, such as the conceptual content of certain sentences, or the perceptual content of certain expressions, do not belong to logic at all, but to psychology. ${ }^{13}$

De allí a declarar "superflua" una lógica del significado no había más que un paso. El contraste con semejantes actitudes lo proporciona ejemplarmente la reformulación del 'principio de tolerancia'.14

The acceptance or rejection of abstract linguistic forms, just as the acceptance or rejection of any other linguistic forms in any branch of science, will finally be decided by their efficiency as instruments (...) To decree dogmatic prohibitions of certain linguistic forms instead of testing them by their success or failure in practical use, is worse than futile; it is positively harmful (...) Let us be cautious in making assertions and critical in examining them, but tolerant in permitting linguistic forms. ${ }^{15}$

Lo que encierra de indudable "autocrítica" la declaración del principio de tolerancia es consecuencia, por una parte, de los intentos, más complejos que exitosos, por lograr la formalización de la semántica, y por la otra, de la admitida influencia de la Escuela Polaca, particularmente Tarski, en la evolución del pensamiento de Carnap. ${ }^{16}$

13 The Logical Syntax of Language, p. 259.

14 Originalmente enunciado en The Logical Syntax of Language ( $\$ 17$ "The Principle of Tolerance in Syntax", pp. $5^{1}$ ss.) y posteriormente citado y utilizado en el Prefacio y en \$ 5 ("Descriptive and Pure Semantics") de Introduction to Semantics. Las diferencias son notables, especialmente entre la primera y la última formulación (citada supra in extenso), pues en The Logical Syntax of Language, el principio en cuestión, tan sólo aplicable a formas lingüísticas científicas (logical systems), se enunciaba escuetamente así: "It is not our business to set up prohibitions, but to arrive at conventions." Por ello, en su autobiografía (cf. The Philosophy of $R$. Carnap, ed. por P. A. Schilpp, vol. XI de The Library of Living Philosophers, La Salle, Ill., 1969), Carnap propone que "it might perhaps be called more exactly the "principle of the conventionality of language forms'" (op. cit., p. 55). El principio se completaba con la conocida expresión: "In logic, there are no morals; everyone is at liberty to build up his own logic, i.e. his own form of language, as he wishes." Mas, para resaltar que en caso alguno se trata de lenguajes naturales, agregaba: "All that is required of him is that, if he wishes to discuss it, he must state his methods clearly, and give syntactical rules instead of philosophical arguments" (loc. cit.).

15 Meaning and Necessity (2nd. ed.), p. 221.

16 "Tarski, both through his book and in conversation, first called my attention to the fact that the formal method of syntax must be supplemented by semantical concepts, showing at the time that these concepts can be defined by means not less exact than 
Al plantearse Carnap, en la cuarta parte ('General Syntax') de The Logical Syntax of Language, el problema de la necesidad o no de una lógica intensional, y tras reconocer que ciertos lógicos venían haciendo esfuerzos por suplementar la lógica común (estilo Russell) con una nueva lógica, denominada lógica intensional o del significado (meaning), se pronuncia por una solución tajante:

A special logic of meaning is superfluous: 'non-formal logic' is a contradictio in adjecto. Logic is syntax..$^{17}$

Las razones que le asistían para así decretar la reducción del edificio lógico a su parte estructural se derivan de la distinción, practicada ad hoc por Carnap, entre 'cuestiones formales' y el 'contenido' material de las cuestiones. Este último puede ser contenido 'conceptual' (propio de determinadas proposiciones) o contenido 'perceptual' (característico de ciertas expresiones). En cualquier caso, "do not belong to logic at all, but to psychology". ${ }^{17}$ Tan fuerte reducibilidad de la totalidad de cuestiones lógicas a cuestiones sintácticas, obliga a Carnap a enunciar un principio de operación lógica estricta aún en el contexto de un lenguaje histórico dado:

It is theoretically possible to establish the logical relations (consequence-relation, compatibility, etc.) between two sentences written in Chinese without understanding their sense, provided that the syntax of the Chinese language is given.18

Carnap hace algo más que separar las cuestiones de significado de las de relación lógica formal (posible posición que llevaría a descartar como impropio de la lógica el tratamiento de las primeras). Lo que hace es reducir las primeras a las sintácticas:

Thus, in the syntax, we have represented the formal side of the sense of a sentence by means of the term 'content'; and the formal side of the logical relations between sentences by means of the terms 'consequence', 'compatible' and the like. All the questions which it is desired

those of syntax. Thus the present book owes very much to Tarski, more indeed than to any other single influence." Introduction to Semantics, ed. cit., p. vi.

"My conception of semantics starts from the basis given in Tarski's work, but differs from his conception by the sharp distinction which $I$ draw between logical and nonlogical constants, and between logical and factual truth", "Autobiography" (in: The philosophy of $R$. Carnap, ed. cit., p. 56).

17 op. cit., p. 259.

18 Ibid.; aunque, a continuación, se matiza la declaración: "In practice this is only possible in the case of the simpler artificially constructed languages", que, en realidad, resultó ser el programa a seguir. 
to treat in the required logic of meaning are nothing more than questions of syntax.19

¿Cómo es posible semejante reducción?

Ante todo, partiendo de una tesis radical restrictiva del objeto de investigación. Carnap se basó en la distinción, por él creada en The Logical Syntax of Language, entre 'object-questions' y 'Jogical questions', 20 considerando además que la totalidad de las "cuestiones objeto" se divide en "legítimas" y "falsas"; las primeras corresponden a las ciencias positivas, mientras que las segundas han de ser descartadas del lenguaje analizado o en vías de formalización. Para una disciplina no coincidente con ninguna de las ciencias empíricas, pero con pretensión de validez formal, sólo subsistirán las "cuestiones lógicas". Al conjunto de tales cuestiones denomina Carnap la "lógica de la ciencia":

According to this view, then, once philosophy is purified of all unscientific elements, only the logic of science remains. ${ }^{21}$

La inferencia obligada es que aquellos problemas filosóficos que aspiren a poseer algún significado han de pertenecer a la sintaxis lógica.

Aparte del aspecto restrictivo (anti-metafísico, propio del espíritu de la época), 'lógica de la ciencia', se toma aquí como término amplio que no sólo cubre problemas estricta o tradicionalmente lógicos, sino que viene a significar la totalidad de problemas planteables tanto en lógica pura como en lógica aplicada, es decir, una especie de metateoría lógica que engloba cuestiones de análisis lógico y de epistemología científica.

Una visión tan reductiva del tratamiento lógico por vía de la postulación metateórica servirá para unificar lo que tradicionalmente se consideraba separado:

According to the usual view, all logical investigation comprises two parts: a formal inquiry which is concerned only with the order and syntactical kind of the linguistic expressions, and an inquiry of a material character, which has to do not merely with the formal design but, over and above that, with questions of meaning and sense. Thus the general opinion is that the formal problems constitute, at the most,

19 Loc. cit. (subrayado nuestro). Como se ve, el principio reductor de Carnap reproduce la 'tesis de la extensionalidad', adoptada por Russell, en la Introducción de la segunda edición de los Principia (1925).

20 'Cuestiones objeto" $=$ "those that have to do with the objects of the domain under consideration".

"Cuestiones logicas" $=$ "do not refer directly to the objects, but to sentences, terms, theories, and so on, which themselves refer to the objects" (cf. op. cit., parte V: 'Philosophy and Syntax', pp. 277 ss).

21 Loc. cit., p. 279 . 
only a small section of the domain of logical problems. As opposed to this, our discussion of general syntax has already shown that the formal method, if carried far enough, embraces all logical problems, even the so-called problems of content or sense. ${ }^{22}$

Se adelanta lo que luego se distinguirá como 'formal mode of speech' y 'material mode of speech', 23 pero conviene subrayar el hecho de que se trata de una unificación formalizante efectuada mediante reducción a la base estructural de la lógica: sintaxis lógica. De esta manera, la tesis unitaria queda establecida en favor de las "cuestiones lógicas", las cuales, no sólo se ocupan de la forma de las expresiones lógicas, sino que comprenden asimismo los aspectos relativos a significado y contenido. De ahí, la un tanto forzada conclusión de Carnap en este punto:

In certain sense, of course, logical questions are also object-questions, since they refer to certain objects - namely, to terms, sentences, and so on- that is to say, to objects of logic.24

Una reducción tan profunda crea, de hecho, cierta confusión objetiva en lo que respecta a la ordenación de las cuestiones según su alcance; esto es, se presenta una interferencia de dominios entre las cuestiones lógicas y las cuestiones-objeto. ${ }^{25}$ Ello obliga a Carnap a refinar esa distinción, mediante la introducción de un género superior para las "logical-sentences", a saber, el de "syntactical sentences", que cubre a "logical-sentences", que versan sobre la forma, y a "logical-sentences", que se refieren al contenido. Quedan separadas, así, "syntactical sentences" y "object sentences", con indicación de cuál es el terreno intermedio entre ambos dominios:

To this intermediate field we will assign the sentences which are formulated as though they refer (...) to objects, while in reality they refer to syntactical forms, and, specifically, to the forms of the designations of those objects with which they appear to deal. ${ }^{26}$

Según ello, una sentencia o se refiere a un objeto directamente (dominio de ciencia singular) o se refiere a un objeto indirectamente, en cuyo

22 Loc. cit., pp. $281-282$.

23 Cf. op. cit. $\S 74$ ("Pseudo-objects sentences"), donde se advertirá también que la distinción entre 'modos' del discurso es, para Carnap, no menos artificial que la existente entre 'cuestiones': "The disguise of the material mode of speech conceals the fact that the so-called problems of philosophical foundations are nothing more than questions of the logic of science, and also the further fact that the questions of the logic of science are formal -that is to say, syntactical- questions" (loc. cit., p. 288).

24 Loc. cit., p. 277.

25 o 'expresiones lógicas' y 'expresiones de objeto' ("logical sentences" y "objectsentences") que son, para el caso, equivalentes.

26 Loc. cit., pp. $284-285$. 
caso, puesto que en realidad se refiere a formas de expresión, cae en el dominio lógico. No hay, por lo tanto, fuera de las “object-sentences" sino las sintácticas. A esas expresiones que son sintácticas por su contenido, aunque se presenten "disfrazadas" de expresiones de objeto, Carnap denomina 'pseudoobject-sentences'.

Ahora la tarea lógica reductiva lo es de traducción; se trata de pasar de unas expresiones que "parecen" referirse a objetos o expresiones sintácticas, de estructura lógica formal. Son, en realidad: "quasi-syntactical sentences of the material mode of speech".27

Por su parte, la exigencia de traducción (de un modo del discurso al otro) se apoya en la tesis unicista del lenguaje formalizado mediante la sintaxis, ya formulada previamente:

It is to be noted that the differentiation between autonymous ${ }^{28}$ and material modes of speech is concerned with interpretation. This means that this differentation cannot be made in relation to a language $S_{1}$ which is given as an isolated calculus without any interpretation. But it does not mean that the distinction lies outside the domain of the formal, in other words, of syntax. For, even the interpretation of a language can be formally represented and thus be incorporated in the syntax.99

Ejemplo de traducción de una 'seudo sentencia de objeto' a 'sentencia sintáctica' es el que proporciona la expresión: "Cinco no es una cosa sino un número" $\left(S_{1}\right)$, que, por la forma, pareciera presentarse como similar a esta otra: "Cinco no es un número par sino un número impar" $\left(S_{2}\right)$, pero que, de hecho, no lo es, ya que la sentencia equivalente a $S_{1}$ es, en realidad: "Cinco' no es una palabra-cosa sino una palabra-número" $\left(S_{3}\right)$. Aquí pueden apreciarse no sólo las distancias reales entre las tres sentencias, sino los niveles de lenguaje que en ellas subyacen; en efecto, $S_{1}$ es lo que Carnap denomina: "pseudo-object-sentence" (o "quasi-syntactical sentence"), y, si $\mathrm{S}_{2}$ es una típica "object-sentence", entonces $S_{3}$ revela la auténtica "syntactical sentence" (correspondiente al dominio de las verdaderas "logical questions"). En cuanto al discurso cubierto por estos tipos de sentencias, su delimitación

27 Idem., p. 285 ; cf. $\& \dot{6}_{4}$ ("The two interpretations of quasi-syntactical sentences"), donde se plantea la cuestión relativa a la 'traducción' del modo material al modo formal del discurso.

28 Equivalente de 'formal', puesto que es introducido por Carnap (op. cit., \& 42; pp. 156 ss.) ante la necesidad de distinguir entre una expresión y su designación: "Since the:- name of a given object may be chosen arbitrarily, it is quite possible to take as a name for the thing, the thing itself, or, as a name for a kind of thing, the things of this kind. We can, for instance, adopt the rule that, instead of the word 'match', a match shall always be placed on the paper. But is more often a linguistic expression than an extra-linguistic object that is used as its own designation. We call an expression which is used in this way autonymous" (loc. cit., p. 156).

20 Loc. cit., p. 299. 
entre el 'modo formal' y el 'material' viene registrada con extensión desigual, pues si $S_{3}$ pertenece plenamente al "formal mode", entonces tanto $S_{1}$ como $S_{2}$ se sitúan en el "material mode of speech".

Un ejemplo más semántico es el de "those logical sentences which assert something about the meaning, content or sense of sentences or linguistic expressions of any domain". ${ }^{30}$ Como el proporcionado por la expresión: "La clase de ayer versó sobre Babilonia" (aún mejor: "La clase de ayer fue sobre Babilonia"). Su correspondencia modal puede disponerse como sigue:

\begin{tabular}{|l|l|l|}
\hline Sentencia-objeto & $\begin{array}{l}\text { Seudo sentencia-objeto } \\
\text { Sentencia cuasi-sintácti- } \\
\text { ca) }\end{array}$ & $\frac{S_{2}}{S_{1}}$ \\
$\begin{array}{l}\text { "Babilonia fue una gran } \\
\text { ciudad" }\end{array}$ & $\begin{array}{l}\text { "Se trató acerca de Ba- } \\
\text { bilonia en la clase de } \\
\text { ayer" }\end{array}$ & $\begin{array}{l}\mathrm{S}_{3} \\
\text { "La voz 'Babilonia' fue } \\
\text { mencionada en la clase } \\
\text { de ayer" }\end{array}$ \\
\hline
\end{tabular}

Para facilitar plena y formalmente la traducción del modo material al modo formal del discurso (o habla), Carnap formula un criterio que es otra forma de expresar la reducción de las expresiones lingüísticas a sus estructuras lógicas (sintaxis):

$S_{1}$ is called a sentence of the material mode of speech if $S_{1}$ asserts a property of an object which has, so to speak, parallel to it, another and syntactical, property; that is to say, when there is a syntactical property which belongs to a designation of an object if, and only if, the original property belongs to the object. ${ }^{3 \mathrm{x}}$

De ahí se desprende, por más que Carnap no considere necesario indicarlo, que la condición de no reducibilidad de una expresión de objeto a su formulación sintáctica es que la primera declare alguna propiedad del objeto que no tenga su correspondiente ("paralela") propiedad sintáctica. Sin embargo, una supuesta propiedad objetiva sin referencia sintáctica (lingüistica) alguna equivaldría, tradicionalmente hablando, a un 'noumenon', por lo cual se vuelve a caer en la obligada inferencia de la absoluta posibilidad de reducción de las sentencias de objeto a sentencias lógicas.

Ahora bien, el que las sentencias formuladas en el modo material del 285 ss.).

30 Las cuales son también, para Carnap, "pseudo-object-sentences" (cf. loc. cit., pp. 31 Loc. cit., p. 287. 
lenguaje sean traducibles, en principio, a otras, formuladas formalmente, no quiere decir que, para Carnap, sea aconsejable la completa eliminación de las primeras, ni siquiera en lo referente a la zona ambigua de sus expresiones cuasi-sintácticas, según parece desprenderse del siguiente pasaje:

We do not mean by this that the material mode of speech should be entirely eliminated. Since it is in general use and often easier to understand, it may well be retained in its place. But it is a good thing to be conscious of its use, so as to avoid the obscurities and pseudo-problems which otherwise easily result from it. ${ }^{32}$

Puesto que la tarea principal que se impone Carnap es de conversión de un modo lingüístico a otro, le resulta obligado efectuar algún tipo de análisis en el nivel material del lenguaje a fin de discernir sobre qué expresiones se llevará a cabo con más provecho y posibilidades de transferencia la traducción propuesta.33 En el curso de ese análisis, se descubrirá que una parte del 'modo material del habla' la forman sentencias tratadas como propiamente semánticas, aunque Carnap las caracteriza como 'sentencias que expresan una relación de designación', entre las que clasifica aquellas en que aparecen una de las siguientes expresiones: "trata de", "habla acerca de", "significa", "quiere decir", "es el nombre de", "designa" y otras semejantes. Técnicamente consideradas son denominadas "sentences concerning meaning". 34 De ellas, son analizadas catorce ${ }^{35}$ a efectos de su conversión, en tanto "quasi-syntactical sentences", que han de ser pasadas a "correlated syntactical sentences". Investiga asimismo otro modo lingüístico que se presenta como sub-conjunto del "material mode"; se trata del "indirect" u "oblique", caracterizado por ciertas conjunciones, como 'que' (that) y 'si' (whether). Se completa el análisis del lenguaje cotidiano con el estudio de aquellas expresiones que contienen 'palabras universales' ("thing", "object", "property", "relation", "event")..$^{36}$

Las conclusiones a las que llega Carnap son: I) no hay seguridad en sostener que el empleo del lenguaje cotidiano produzca contradicciones o

32 Loc. cit., p. 288 . Los representantes analíticos, defensores de tesis pragmatistas, pueden encontrar cierto apoyo en esa petición de Carnap para 'ser conscientes' del uso del lenguaje cotidiano.

533 Las expresiones elegidas por Carnap (cf. op. cit., \& 75, "Sentences about Meaning") revelan la principal tendencia "ideológica" de los adscritos, para la época, de una u otra manera, al positivismo lógico en su expresión anti-metafísica, ya que se decide a investigar aquellas expresiones que se utilizan frecuentemente en la argumentación filosófica. La nota de optimismo, característica de la "ideologia" subyacente, se concentra en la siguiente declaración: " (...) by this means the whole character of philosophical problems will become clearer to us" (loc. cit.).

34 De las cuales, su misma denominación es el más inmediato ejemplo, en tanto expresion autológica.

35 Cf. loc, cit., pp. $289-290$.

36 Cf. op. cit., pp. 292-298. 
conduzca a contradicciones necesarzamente, por una razón, con la que se muestra una mayor coherencia en este punto que Tarski:37 "the word-language is not bound by the rules of logistics"; 38 2) sin embargo, si el empleo del lenguaje cotidiano (o, al menos, de la forma material del mismo) trae como consecuencia la formación de contradicciones (casi siempre, e histó ricamente registradas, en tanto paradojas), ello se debe a que se aplican en él irreflexivamente ("thoughtlessly") aquellos métodos inferenciales cuyo uso tiene sentido y es correcto en otros lenguajes o en el modo formal del habla; 3) en cualquier caso, aun en el supuesto optimista de que el lenguaje coloquial no conduzca a contradicciones (o se rechace el concepto mismo de 'contradicción' por impropio dentro de un lenguaje no estrictamente lógico), su empleo no es recomendado científicamente por cuanto resulta fácilmente decepcionante para los fines semánticos propios de cualquier lengua. En efecto, si el habla persigue, como fin último, la referencia a objetos (designata), un lenguaje cotidiano en su modo material no alcanza dicho fin: "one believes that one is investigating certain objects and facts, whereas one is, in reality, investigating their designations, i.e., words and sentences". ${ }^{39}$ Esta es probablemente la más fuerte de las tres conclusiones, ya que, de ser aceptada, sitúa al lenguaje material como lenguaje no-semántico, pero puesto que, a su vez, previamente, se le ha concedido la no aplicabilidad de los principios lógicos en su uso, resulta ser también un lenguaje no-sintáctico. Su nivel semiótico queda, pues, reducido al de la pragmática, con lo que se refuerza indirectamente la tesis central del primer Carnap, que aquí se comenta, a saber: la semántica es una parte de la sintaxis lógica. Prueba de ello es que el modo material del habla, por no ser coherente (mejor dicho: por no tener sentido en él la atribución de coherencia en tanto que no le convienen las reglas sintácticas), ni siquiera se auto-trasciende, en tanto juego de palabras, hacia unos supuestos designata.

En líneas generales, Carnap termina caracterizando el modo material del habla como un tipo especial de lo que denomina "transposed mode of speech".40 Un modo 'transpuesto' del habla es aquel en el que, al querer aseverar algo acerca del objeto ' $a$ ', lo que se hace en realidad es aseverar algo correspondiente acerca del objeto ' $b$ ', que mantiene una determinada relación con ' $a$ '. No hay contradicción entre esta caracterización y la principal consecuencia extraída de la tercera de las conclusiones anteriores, según la cual se le niega, de hecho, al lenguaje material alcances semánticos. Lo que sucede, sin que Carnap lo explicite así, es que el supuesto objeto ' $b$ ' sobre el que se aserta algo en el modo material no es tal "objeto" (ontoló

37 Cf. pp. 92-93 supra.

38 Op. cit., p. 291.

39 Ibid., p. 312.

40 Op. cit., p. 308. 
gicamente hablando) sino un objeto lingüístico más (palabra o sentencia). La carencia de designata, propia del lenguaje cotidiano, es matizada de esta manera como carencia de designata extra-lingǘsticos, con lo cual se le otorga implícitamente al modo material del habla un papel metalógico. El lenguaje coloquial lo es de otro lenguaje o de partes del lenguaje. Pero lo mismo sucede con el modo formal del habla, por lo que queda autorizado, una vez más, el proceso de traducción de uno, imperfecto y 'disfrazado' (el modo material) a otro, explícito y directamente lógico (el modo formal):

Our investigations have shown that the supposititious object-sentences of the logic of science are pseudo-object-sentences, or sentences which apparently speak about objects, like the real object-sentences, but which in reality are speaking about the designations of these objects. This implies that all the sentences of the logic of science are logical sentences; that is to say, sentences about language and linguistic expressions. And our investigations have further shown that all these sentences can be formulated in such a way as to refer not to sense and meaning but to the syntactical form of the sentences and other expressions - they can all be translated into the formal mode of speech, or, in other words, into syntactical sentences. ${ }^{41}$

La primera gran rectificación de Carnap a sus posiciones originales viene indicada en la Introduction to Semantics. 22 Si hasta esta obra todo lo que no fuera análisis lógico (sintáctico) del lenguaje formaba parte de una investigación psicológica (pragmática) del mismo, a partir de ahora se admitirán tres posibles tipos de análisis lingüístico para dar entrada a la tercera gran región de la semiótica (semántica):

(...) it was asserted [en The Logical Syntax of Language] that an analysis of language is either formal, and hence syntactical, or else psychological. Today I would say that, in addition to these two kinds of analysis (the second is what is now called pragmatical), there is the possibility of semantical analysis. Hence I no longer believe that " $a$ logic of meaning is superfluous"; I now regard semantics as the fulfillment of the old search for a logic of meaning, which had not been fulfilled before in any precise and satisfactory way. ${ }^{43}$

Independientemente del cambio que significa el aumento del terreno a investigar, mediante el proceso de señalarse la tarea de construcción de una disciplina especifica que satisfaga a una 'lógica del significado', se produjo

41 Op. cit., p. 315 (subrayado nuestro).

42 En $\$ 39$ ("Remarks on 'Logical Syntax" ") que, a su vez, forma parte de un Appendix a la obra en referencia (cf. nota 12 de la p. 93 supra).

43 Loc. cit., p. 249. Cf. también la p. 246: "The field of theoretical philosophy is no longer restricted to syntax but is regarded as comprehending the whole analysis of language, including syntax and semantics and perhaps also pragmatics...". 
también, dentro de la evolución temática de la obra de Carnap, la variación de las tesis metodológicas que sustentaban su primera filosofía analítica del lenguaje. Las dos tesis originales declaraban: a) la filosofía (teorética) es la lógica de la ciencia; b) la lógica de la ciencia es la sintaxis del lenguaje de la ciencia. A partir de la etapa de Introduction to Semantics, la primera tesis es conservada tal cual, pero la segunda exige modificaciones:

Thus the whole thesis is changed to the following: the task of philosophy is semiotical analysis; the problems of philosophy concern -not the ultimate nature of being but- the semiotical structure of the language of science, including the theoretical part of everyday language. ${ }^{44}$

Antes de entrar en la determinación de esa "parte teórica del lenguaje cotidiano", que forma la estructura del lenguaje de la ciencia, conviene averiguar la causa de tal variación en el enfoque semiótico de Carnap y proceder a describirla.

Como razón primordial del cambio registrado, el propio Carnap señala la influencia que ejerció sobre él el pensamiento de Tarski en esta materia. ${ }^{45}$ Ahora bien, no deja de resultar un tanto extraño que un autor que, como Tarski, se caracterizó muy claramente por su oposición razonada a cualquier posibilidad de constitución de una semántica formalizada del lenguaje cotidiano, haya determinado en otro autor el cambio que lleva a éste a reivindicar tal posibilidad, al menos para una "parte del lenguaje corriente". Quizás por lo mismo, Carnap expresa sus diferencias con Tarski, sin dejar de admitir la influencia ejercida. En algunas de las diferencias señaladas ${ }^{46}$ es posible percatarse de una de las razones básicas de Carnap para su parcial valoración de la semántica del lenguaje ordinario. Dos son las grandes zonas de divergencia entre Carnap y Tarski sobre concepción de la semántica. Por un lado, mientras Carnap quiere distinguir entre sistemas semánticos interpretados y no interpretados (cálculos puramente formales), Tarski no practicó nunca tal distinción, justamente en la medida en que postulaba una formalización absoluta, sin posibilidad de interpretación, la cual exige la admisión de designata interpretativos. Por otra parte, en el terreno específicamente semántico, Carnap va a crear otra de esas distinciones que Tarski no reconoce como necesarias, o que, al menos, no estableció por su parte. Se trata de la separación entre tipos de verdad: 'verdad material' (factual truth para Carnap) y 'verdad formal' (logical truth). La primera, como es sabido, reposa sobre la contingencia de los hechos y la segunda depende del significado de los términos empleados. Ciertamente que esto indica la debilidad postulativa de Carnap frente a Tarski, pues explicar

44 Op. cit., p. $25^{\circ}$.

45 Cf. nota 16 de la p. 94 supra.

46 Cf. en op. cit., p. vii del Prefacio. 
la necesidad de un tratamiento semántico del lenguaje ordinario (o de parte de él) mediante la diferenciación entre verdades (material-formal) $y$, a continuación, introducir el concepto de 'significado' (meaning) para caracterizar a la verdad lógica frente a la factual, revela una cierta circularidad en el razonamiento de la fundamentación semiótica. De paso, muestra la importancia que, en Carnap, como en Tarski, tiene el concepto de verdad. No parece aventurado sostener que según sea la teoría de la verdad así será la concepción semántica de un autor.

Sobre la doble divergencia señalada, reconocida por Carnap, el comentario de éste tiende a establecer una base o raíz común que, de hecho, funcionaría como tercera y fundamental diferencia entre los dos autores. Se trata de la distinción entre 'signos descriptivos' y 'signos lógicos', explicitada por Carnap en el $\S 13$ ("Logical and Descriptive Signs") de la obra aquí comentada. Si (a grandes rasgos) los 'signos descriptivos' son los que sirven para designar cosas o sucesos y sus propiedades o relaciones, mientras los signos lógicos equivalen a las constantes o conectivas sentenciales, es evidente que, por la condición de "variable" propia de los primeros, están sujetos a interpretación; pero no se trata de una interpretación lógica, de nivel sintáctico, como lo es el remplazo de ' $\mathrm{f}$ ' en ' $\mathrm{f}(\mathrm{x})$ ' o de ' $\mathrm{p}$ ' en 'p.q' por un término ("hombre") o una proposición ("Sócrates es hombre"), respectivamente, sino del remplazo de un término o de una proposición por su 'significado'. Luego es una interpretación "semántica", con lo que nuevamente reaparece la circularidad indicada. Mal podía Tarski aceptar la distinción radical entre 'signos descriptivos' y 'signos lógicos' si a los primeros se les define a través del 'significado', pues esto equivale a admitir la posibilidad de un tratamiento lógico de ciertos términos o expresiones del lenguaje cotidiano. Éste es un punto en el cual, a la resistencia técnica de Tarski, basada en la imposibilidad establecida de fundamentar ninguna relación semántica a partir del "modo material" del lenguaje, se agregan las prevenciones generales de los empiristas lógicos ante el peligro de una 'semántica general' que reintroduzca la rechazada metafísica:

They seem to think that pragmatics - as a theory of the use of language - is unobjectionable, along with syntax as a purely formal analysis; but semantics arouses their suspicions. They are afraid that a discussion of propositions - as distinguished from sentences expressing them- and for truth - as distinguished from confirmation by observations- will open the back door to speculative metaphysics, which was put out at the front door. ${ }^{47}$

La reacción de Carnap frente a semejantes actitudes de cautela es de fndole práctica y viene a continuar la línea "convencionalista", iniciada en 
The Logical Syntax of Language, ${ }^{48}$ que culmina en el 'principio de tolerancia':

It seems to me that the only question that matters for our decision in accepting or rejecting a certain concept is whether or not we expect fruitful results from the use of that concept, irrespective of any earlier metaphysical or theological doctrines concerning it.49

Sin embargo, de la disciplina cuya construcción emprende Carnap en la obra tratada se va a esperar algo más que un aporte de benéficos resultados: "semantics will not only be of accidental help to pure logic but will supply the very basis for it". ${ }^{50}$ La concepción piramidal de la semiótica reaparece en una de las últimas grandes obras de Carnap, Logical Foundations of Probability, en donde la semántica sigue siendo postulada como la base del edificio lógico que, por su parte, queda dividido en dos grandes géneros: lógica deductiva y lógica inductiva. Puesto que la lógica deductiva ha sịdo previamente construida y definida como la teoría de "conceptos-L" (o conceptos lógicamente definidos en un sistema formal) y, a su vez, tales conceptos se derivan del concepto semántico de 'dominio' (range), puede sostenerse, en consecuencia, que la lógica deductiva forma parte de la semántica (lo que Carnapp denomina "semántica-L"). Por su parte, la lógica inductiva es tratada como la teoría de $\mathfrak{C}^{51}$ y el concepto $\mathfrak{C}$, a su vez, vuelve a derivarse del concepto de 'dominio'; además, los teoremas de la lógica inductiva que, en la obra citada, obtendrá Carnap, no sólo tratarán con el concepto básico de "grado (métrico) de confirmación", sino también con "conceptos-L" (como el de "implicación-L"); por todo ello asimismo la lógica inductiva pertenece a la semántica, desde este punto de vista.

El plan de trabajo de Carnap, a partir de Introduction to Semantics, exigía un desarrollo por etapas a fin de cumplir con el objetivo de constitución de una semántica general o teoría de la semántica. Las dos etapas principales, originalmente previstas, se registran en la obra comentada (Intr. to Sem.), la cual proporcionaría una introducción general a la materia y permitiría la explicación de los conceptos de mayor importancia, mientras que, en el 'segundo volumen' de la serie ("Studies in Semantics"), es decir, Formalization of Logic, se acomete de lleno el problema de la posibilidad de una formalización total (full formalization) de la lógica y del modo de llevarla a cabo. Para ello, será necesario considerar a la lógica como un

48 Cf. nota 14 de la p. 94 supra.

49 Loc. cit., p. viii (subrayado nuestro).

50 Ibid.

51 C es el 'grado (métrico) de confirmación', pues la fórmula de la que procede, $\mathfrak{C}(h, e)=q$, significa "grado de confirmación de $h$ en $e=q$ ", donde ' $\mathrm{q}$ ' es cualquier número del intervalo (0.1). 
sistema semántico, cuya formalización consiste en la construcción del cálculo correspondiente (esto es, la formación del sistema sintáctico):

A full formalization would be a calculus which mirrors all essential properties of the system of logic in a formal way such that the intended interpretation is the only one possible. ${ }^{52}$

Quizás este punto señale mejor que ningún otro toda la distancia que media entre el Carnap de The Logical Syntax of Language y el de Introduction to Semantics. En efecto, en la Parte V ("Philosophy and Syntax") del primero de los libros citados, se criticaba la formulación de "propiedades esenciales", bajo la distinción de "propiedades internas (= esenciales)" y "propiedades externas", por considerarla causa de innumerables discusiones y controversias filosóficas, calificadas por Carnap de 'hueras' (idle). Lo que se proponía era la radical solución de la traducción al modo formal del lenguaje $^{53}$ de aquellas expresiones contentivas de referencias a 'propiedades'. Pero, a partir de Intr. to Sem. Carnap vuelve a emplear ${ }^{54}$ un término que, no sólo había sido criticado en tanto ambiguo, sino que había sido propuesto como ejemplo para ejercitar la solución translativa entre modos del lenguaje, lo cual lo convertiría en formulación "so simple that no one can any longer be tempted to raise philosophical problems about it".55 Ahora son precisamente las "propiedades esenciales" de un sistema lógico, entidades a decir verdad un tanto míticas y no definidas, las que quedarán reflejadas en un cálculo que formalice a dicho sistema. De manera indirecta, se abre por aqui el problema relativo a la extensión de la formalización de la semántica carnapiana o, para enunciarlo de manera más intuitiva, los límites de lo que se puede y de lo que no se puede formalizar en la constitución de un sistema lógico a partir de términos semánticos básicos. La presentación organizada de dicho problema, así como el señalamiento de su solución pertenece al $\S$ i ("The Problem of a Full Formalization of Logic") del segundo volumen de los Studies in Semantics. ${ }^{50}$

62 Loc. cit., p. ix.

53 Cf. pp. 97 ss., supra.

54 La misma noción reaparece en Formalization of Logic con motivo del problema (tratado aquí mismo) de la "formalización integral" de la logica: "If the question is taken simply in ordinary sense, as referring to a formalization of logical deduction -in other words, to a formalization of the relation of L-implication- then the answer is of course in the afirmative (...) But we will take the question here in a stronger sense. If a calculus $\mathrm{K}$ containing the ordinary connectives of propositional logic could be constructed in such way that it would formalize all essential properties of these connectives so that it would exclude the possibility of interpreting the connectives in any other than the ordinary way, then we should say that $\mathrm{K}$ was a full formalization of propositional logic" (p. 4, subrayado nuestro).

55 Loc. cit., p. 304 .

56 Se pueden formalizar: a) ciertas características semánticas de las expresiones lingüisticas (por ejemplo: puede formalizarse o como dice Carnap ser "mirrored in a syntac- 
Se ha visto que, en definitiva, por 'formalización integral' Carnap entiende, a través de la construcción de un cálculo, el tratamiento sintáctico de la semántica. Esa suerte de híbrido (una semántica sintáctica) revela la comunidad de investigaciones que se establece entre ambos terrenos que, a su vez, es consecuencia del esfuerzo modificativo de Carnap por ampliar la sintaxis lógica de la que había partido. Terminológicamente se plantea el curioso problema secundario de la denominación unívoca de la confluencia de ambos dominios; "curioso" en tanto que la formalización de la semántica crea un problema de designación: ¿cómo denominar el dominio de investigación?:

This treatise [se refiere a Introduction to Semantics] is devoted to pure semantics and pure syntax ['puro' se opone aquí a 'descriptivo'] or rather to the field in which semantical systems and syntactical systems, and in addition their relations, are analyzed. ${ }^{57}$

Por detrás del problema terminológico se ve la concepción de Carnap sobre semántica y su delineación respecto de sintaxis $\mathrm{y}$, de paso, vuelve a insistirse en el problema de la posibilidad de una formalización integral de la primera.

En consecuencia, el programa de formalización no sólo afectará al cálculo sintáctico (primera etapa ya cumplida) sino a ese dominio superpuesto constituido por el cálculo sintáctico y su interpretación (que es lo que propiamente forma la zona semántica). El trabajo förmalizativo de Carnap se concentra en las siguientes cuatro fases: 1 ) clasificación de signos (constantes, variables, etc.), que son los que designan propiedades o relaciones; 2) construcción de las reglas de formación del sistema; 3) construcción de las reglas de designación; 4) construcción, por último, de las reglas de verdad. Las propiedades que se clasifican en $r$ ), a saber, propiedades propiamente tales (verdad, falsedad) y relaciones (implicación,

tical way", el hecho de que una cierta sentencia sea verdadera, propiedad del orden semántico): "In general, we might define the concept of formalization of a semantical property in the following way. A radical semantical property $\boldsymbol{F}$ of an expression $\boldsymbol{F}_{\mathbf{1}}$ is formalized in $K=D f \mathfrak{H}_{1}$ has the property $F$ in every semantical system which is a true interpretation for $K$. And an $L$-semantical property $F$ of $\mathbb{H}_{i}$ is formalized in $K=D f \boldsymbol{d}_{1}$ has $F$ in every L-true interpretation for $K$ "; $b$ ) las relaciones semánticas: "Analogously for semantical relations".

Pero no se pueden formalizar los designata cuando corresponden a "descriptive signs": "Having a certain designatum is also a semantical property of an expression. It is easy to see that, in the case of a descriptive sign, a property of this kind cannot in general be formalized. Thus e.g. it is not possible to formalize the property of ' $a$ ' designating Chicago and the property of ' $p$ ' designating the property of being large -in other words, it is not possible to construct a calculus $K$ in such a way that in every true interpretation for $K$ ' $\mathrm{a}$ ' and ' $\mathrm{P}$ ' have the designata mentioned. If a true interpretation for $K$ with these designata is given, another true interpretation for $K$ with different designata can always be constructed" (Formalizaion of Logic, pp. 3-4).

57 Introd. to Semantics, p. 14. 
disyunción, etc.) constituyen los "conceptos radicales" y son definidos a partir de la fase 4), esto es, mediante el conjunto (semántico) de las reglas de verdad. Una gran importancia tiene el explicatum de los conceptos lógicos en tanto soporte de la noción de 'verdad analítica'. Dicho explicatum lo obtiene Carnap a partir de los "conceptos-L", correlato lógico de los "conceptos radicales", aunque de menor extensión (indican que si una proposición es L-verdadera es verdadera, como estableció Tarski). Los "conceptos radicales" se distinguen de los "conceptos-L" porque los últimos no poseen dominio (range) de connotación empírica, condición no necesaria de ser cumplida por los conceptos radicales. De donde, nuevamente, se puede apreciar la razón de las divergencias Tarski-Carnap, pues si, para obtener los conceptos-L (elementos formales del sistema lógico), se hace uso de los conceptos radicales, y si éstos coinciden, de hecho, con las expresiones factuales, vuelve a producirse la interacción negada por el primer Carnap entre dominio lógico de la sintaxis y dominio empírico aportado por los designata semánticos.

La lógica ha dejado de ser únicamente cálculo para exigir la interpretación de algunos de sus componentes; al cálculo, propio de la parte estructural o sintáctica, se le agregan los explicata que interpretan los conceptos. Sin embargo, no se trata de un simple y mecánico agregado, sino de una transformación completa del sistema ya que, en definitiva, hasta el cálculo quedará interpretado a través de los explicata; de esta manera, un cálculo cualquiera (por ejemplo, el proposicional) está interpretado lógicamente, según Carnap, cuando todos y cada uno de sus signos están representados en el sistema semántico por conceptos-L, pudiendo entonces hablarse de "interpretación-L" del sistema; ello significa, en consecuencia, una inversión completa de las relaciones originales: ahora la lógica (propiamente los conceptos-L) es una parte de la semántica. Se trata de una reordenación sistemática en las relaciones sintaxis-semántica que viene exigida por la necesidad de interpretar los signos manejados en un cálculo (se echa mano del nivel semántico) $\mathrm{y}$, posteriormente, los pertenecientes al metalenguaje interpretativo:

While the syntactical terms used by logicians are exactly defined and belong to a well-constructed and recognized theory (namely syntax) the same is not true for the semantical terms. These are merely explained in an informal manner, without a theory as framework for them. No rules constituting semantical systems corresponding to the calculi in question are given; although such rules would serve as a basis for the semantical terms used. Thus the understanding and the use of these terms is left to common-sense and instinct. It is assumed that the reader knows how to interpret and use them on the basis of his knowledge of everyday language. 58

58 Formalization of Logic, Preface, p. xll. 
El remedio a la formación de semejante zona de oscuridad lingüistica vendrá dado por la formalización del nivel semántico:

We can see that, in order to improve the method of logic, we need: a systematically constructed semantics as urgently as we previously needed a systematically constructed syntax (theory of proof).$^{59}$

A partir de semejante toma de posición, doble será el camino seguido por Carnap en la tarea de formalización de la semántica, según que se dé preferencia a la totalidad lingüística (relación estructural sintáctica) o a ciertos elementos sueltos de esa totalidad (conceptos-L). En el primer caso,. se desarrolla el 'método de formalización absoluta o integral' propio de la obra Formalization of Logic; al seleccionar ciertos términos, elaborará el 'método de extensión $e$ intensión', caracteristico de Meaning and Necessity. Independientemente de las limitaciones teóricas del primer método. (según sus resultados), ${ }^{60}$ su fundamentación operativa reposa sobre la acepción que da Carnap, en la obra citada, al concepto 'formal'.

Puesto que sólo admite una acepción "fuerte" del término, equivalente a 'sintáctico',61 su aplicación sólo será posible en lenguajes de estructura bien definida mediante reglas precisas. Por el contrario, al querer determinar el alcance de determinados conceptos básicos ('clase', 'propiedad'). habrá de limitarse a lenguajes "of a relatively simple structure" 62 Con el segundo método ("de extensión e intensión"), de hecho Carnap vuelve a manejar un procedimiento de raigambre polaca, pues fue Tarski quien decidió el tratamiento semántico mediante la interpretación aislada de ciertos. conceptos ('verdad', 'satisfacción', 'consecuencia', etc.). ${ }^{63}$ Aunque la finalidad perseguida por Carnap varia respecto de Tarski, ya que trata de demostrar, por un lado, la íntima relación existente entre los conceptos estudiados.

59 Loc. cit., p. xiii.

60 Cf. pp. 106-7 y especialmente, nota $5^{6}$ supra.

a1 Son tres las acepciones que, en sus "Studies in Semantics", introduce Carnap para: trabajar con el término 'formal', a saber: (I) 'general'; (II) 'lógicamente valido'; (III) 'abstrayéndolo del significado' ('prescindiendo del significado': "in abstraction from the meaning") o 'sintáctico'; las tres van en orden creciente de "fuerza" de significado, siendo. de mayor importancia la distinción entre los niveles (II) y (III): "in using the term 'formal' in meaning II, abstraction is made from the meaning of the descriptive signs but not from that of the logical signs. (Thus, for instance, the sentence 'P(a) $\mathbf{v} \sim \mathbf{P}(a)$ " is called formally true (II) because its truth is logically necessary on the basis of the meaning of ' $v$ ' and ' $\sim$ ', as given by the truth-tables, independent of the meaning of ' $P$ ' and 'a'.) On the other hand, in the method which we call formal (in meaning III) or syntactical, abstraction is made from the meaning of all signs, including the logical ones. (For instance, in a suitable calculus, the sentence ' $P(a) v \sim P(a)$ ' is shown to be C-true. -provable- on the basis of rules which are formal in the strict sense III inasmuch as: they do not refer to the meaning of any signs, not even of the connectives" (Formalization: of Logic, p. 6).

62 Meaning and Necessity, Preface, p. iii.

63 Cf. p. 93 supra. 
(que le permite pasar de uno a otro), y, por otra parte, aspira construir, a partir de su análisis, un metalenguaje que sea neutral respecto de los términos básicos:

The method of extension and intension needs only one expression to speak about both the property and the class and, generally, one expression only to speak about an intension and the corresponding extension (...) a metalanguage will be constructed which is neutral with regard to extension and intension, in the sense that it speaks not about a property and the corresponding class as two entities but, instead, about one entity only (..) The possibility of this neutral language shows that our distinction between extension and intension does not presuppose a duplication of entities. ${ }^{64}$

La aparente novedad metodológica del Carnap de Meaning and Necessity queda disminuida cuando se comprende que el método de extensión e intensión es, en definitiva, la teoría generalizada de los conceptos radicales y los conceptos-L. Nuevamente, la distinción entre entidades referenciales y entidades estructurales proporciona la base para establecer alguna relación entre semántica y sintaxis y, a partir de ella, fundamentar un tipo de semántica estructural o formalizada.

Carnap explicita su propio método al compararlo con cierta conocida distinción de Quine: ${ }^{65}$

The theory of relations between a language -either a natural language or a language system - and what language is about may be divided into two parts which I call the theory of extension and the theory of intension, respectively (...Quine calls the two theories 'theory of reference' and 'theory of meaning', respectively...) The first deals with concepts like denoting, naming, extension, truth, and related ones $(.$. The theory of intension deals with concepts like intension, synonymy, analiticity, and related ones.6s

Los ejemplos presentados son de cualidad y nombre. "Blau", en alemán, denota un objeto azul; su extensión es la clase de los objetos azules; en la misma lengua referencial, "der Mond" es el nombre de la luna; luego, la expresión "der Mond ist blau" es verdadera si y sólo si la luna es azul (esquema de Tarski, que sigue válido). A su vez, la intensión de "blau" es la propiedad de ser azul; por lo que se llega a la conclusión de que dos predicados son sinónimos si y sólo si poseen la misma intensión. De paso, Carnap presenta su criterio de analiticidad, ${ }^{67}$ según el cual una sentencia

64 Op. cit., p. 2.

65 En "Dos dogmas del empirismo" de From a logical point of view.

66 "Meaning and Synonymy in natural languages" (in: Meaning and Necessity, p. 233).

67 Criticado por Quine (op. cit.). con el argumento de que presupone, de alguna 
es analítica si es verdadera por la intensión de las expresiones que la forman.

En conjunto, puede afirmarse que, aun en la fase superior de la obra lógica de Carnap, subsiste, por una parte, la preferencia por desarrollar la investigación semántica en el terreno formal $\mathrm{y}$, por otra, se mantiene el interés en la formación de lenguajes artificiales (sistemas):

For those who want to develop or use semantical methods, the decisive question is not the alleged ontological question of the existence of abstract entities but rather the question whether the use of abstract linguistic forms or, in technical terms, the use of variables beyond those for things (or phenomenal data), is expedient and fruitful for the purposes for which semantical analysis are made, viz. the analysis, interpretation, clarification, or construction of languages of communication...68

Lo que defiende Carnap no es únicamente la vieja tesis central de la posibilidad de formalización estructural de la semántica (o de sus principales términos cuando menos), sino el criterio determinante de su "principio de tolerancia", relativo a la "practicidad" (por beneficios de uso) del método adoptado. ${ }^{69}$

Subsiste, asimismo, la contención y sentido de limitación respecto del desarrollo de la semántica en tanto disciplina específica, pues se la sigue considerando como una técnica en gestación, susceptible de cambios fundamentales desde el punto de vista metodológico. Para ello, sirve el recurso muy general al principio de convencionalidad. Amparado en él, acomete Carnap la tarea de penetrar de alguna manera en un terreno que, para Tarski, era terreno autoprohibido (en tanto "semánticamente cerrado"70), a saber, el propio de los lenguajes naturales.

Allí le servirá, al menos programáticamente, la postulación del método manera, la noción de analiticidad, sin aportar, sin embargo, ayuda alguna para su comprensión.

68 Op. cit., pp. 220-221.

69 Cf. su actitud en "Meaning and Synonymy in natural languages" frente a las criticas de Quine: "some of the objections raised against these semantical concepts concern, not so much any particular proposed explication, but the question of the very existence of the alleged explicanda [lo que, en otro lugar, denomina 'cuestión ontológica']. Especially Quine's criticism does not concern the formal correctness of the definitions in pure semantics; rather, he doubts whether there are any clear and fruitful corresponding pragmatical concepts which could serve as explicanda. That is the reason why he demands that these pragmatical concepts be shown to be scientifically legitimate by stating empirical, behavioristic criteria for them. If I understand him correctly, he believes that, without this pragmatical substructure, the semantical intension concepts even if formally correct, are arbitrary and without purpose. I do not think that a semantical concept, in order to be fruitful must necessarily possess a prior pragmatical counterpart. It is theoretically possible to demonstrate its fruitfulness through its application in the further development of language systems" (loc. cit., pp. 234-235).

70 Cf. p. 92 supira. 
de extensión e intensión lingüística, pues, a la estructuración del edificio lógico que señalaba a la semántica como base del mismo, se agrega la indicación de comenzar por una teoría de la intensión si se quiere analizar con fines formalistas el lenguaje natural. Será cuestión de comenzar por la teoría de la intensión $y$, sobre ella, edificar la correspondiente a la extensión de los términos tratados: "thus, the theory of intension of a given language $L$ enables us to understand the sentences of $\mathrm{L}^{\prime \prime} .^{71}$ Lo cual no ha de ser entendido como petición de una reducción de los conceptos semánticos a una base material (= pragmática) de interpretación de los mismos o de su justificación. Justamente en esto es en donde Carnap se diferencia radicalmente de Quine; ante las dudas de Quine, ${ }^{72}$ acerca de la posibilidad de manejar explicanda de los conceptos semánticos, Carnap aclara la relación existente entre pragmática y semántica: la eficacia y aprovechamiento (fruitfulness) de los conceptos semánticos se deriva de su aplicabilidad en la constitución de sistemas lingüísticos. Con ello, sin embargo, la posición de Carnap parece caer peligrosamente en la prohibición de Tarski; precisamente por no haber revelado ninguna posibilidad de manejo (y menos de aplicación) en el tratamiento de situaciones-límite del lenguaje natural (paradojas), es rechazado el intento de organización investigativa a partir de los términos propios del lenguaje cotidiano. Lo arriesgado de la posición de Carnap realza la importancia del trabajo dedicado a este punto (se trata del ya mencionado "Meaning and Synonymy in natural languages"), en el que se quiere probar que el análisis intensivo, además de ser un procedimiento plenamente científico, posee la seguridad operativa de un análisis de extensión.

Para ello, procede Carnap, en primer lugar, a establecer la determinación (aproximada) del concepto mismo de 'intensión' y, luego, a formular su tratamiento por vía empírico-hipotética. En el primero de los pasos descritos, se muestra cómo 'intensión' (que remplaza al más ambiguo término de 'significado': meaning) ha de ser aplicado únicamente al "cognitive or designative meaning component", lo cual no deja de ser una manera de continuar girando en torno a la ambigüedad que se quiere evitar. Véase cómo: 'intensión' es término intuitivamente entendido como revelador del sentido de una expresión; en su aproximada definición, Carnap lo presenta como correlativo de un supuesto 'significado cognitivo' que, a su vez, es caracterizado como el 'componente de significado' (meaning component) que permite determinar la verdad de esa expresión. La vaciedad formal de la tesis (equivalente al repetido esquema de Tarski para la descripción de verdad' de una sentencia) queda complementada, en el dominio pragmático, mediante la referencia al procedimiento hipotético, característico del conoci- 
miento empírico. Se acepta que 'intensión' es una hipótesis a comprobar y se propone que su comprobación corresponda a algún procedimiento de conducta lingüística: "like any other hypothesis in linguistics can be tested by observations of language behavior". Esto es: se trata de admitir convencionalmente una base factual (pero no una simple elección) para la designación predicativa de un concepto. Se utilizan, como aclaratoria particular, algunos ejemplos. Atribúyase a términos de una lengua natural (alemán) diversos significados (o designación de propiedades: intensión). Así: (1) "Pferd" = caballo; (2) "Pferd" = caballo o unicornio; (3) "Einhorn" = unicornio; "Kobold" = duende; (4) "Einhorn" = duende; "Kobold" = unicornio. Entonces, arguye Carnap, si la tesis extensionalista fuera cierta (1) y (2), por un lado, y (3) y (4), por otro, no presentarian entre sí diferencias. La selección de un significado frente a otro sería tan sólo cuestión o de arbitrio no justificado o de determinada y aceptada tradición lexicográfica. De lo que se trata, según el criterio verificativo de la tesis intensionalista que propone ahora Carnap, es de comprobar empíricamente la hipótesis avanzada para cada caso. Para lo cual, habría que proceder mediante el recurso de preguntas al usuario (alemán) de los términos, el cual, al responder, ha de tener en cuenta no sólo los casos reales de aplicación de significado, sino también los posibles (terreno de modalidad intensional), hasta así lograr la eliminación de alguna de las designaciones y aceptación de otras. ¿A qué conduce semejante procedimiento de comprobación estadísticopragmática? No a otra cosa sino al concepto (extensivo) de 'dominio' o 'alcance' (range) ${ }^{73}$ del predicado examinado; a su vez, el 'dominio' "comprehends those possible kinds of objects for which the predicate holds". Obsérvese que 'clases de objetos' es decididamente un concepto extensional.

Por lo demás, Carnap admite que, al proceder así, puede surgir la dificultad de crear una zona de indeterminación en la designación de la intensión del predicado que denomina, en consecuencia, "intension vagueness". Pero se propone que, en este caso, la 'vaguedad intensional' sea eliminada o, al menos, reducida mediante un procedimiento inductivo de prueba (un manual, por ejemplo, dirigido a las encuestas entre usuarios del lenguaje). Todo esto sitúa a la semántica filosófica extrañamente cerca de la semántica filológica, ${ }^{74}$ puesto que se concibe al lenguaje como un fenómeno em-

73 Básico también en Logical Foundations of Probability para la distinción y fundamentación de las regiones lógicas (cf. pp. 104 ss, supra).

74 Aproximación no aceptada, por lo general, por la línea filosófica. Cf. A. Hofstadter ("On semantic problems", in The Journal of Philosophy, xxxv, 1398, cit. por S. Ullmann: The principles of semantics, Oxford, 1959), siendo Ayer (en Language, Truth and Logic) quien ha destacado más claramente las diferencias radicales: "To say of them [las proposiciones filosóficas] that they are, in some sense, about the usage of words, is, I believe, correct but also inadequate; for certainly not every statement about the usage of words is philosophical. Thus, a lexicographer also seeks to give information about the usage of words, but the philosopher differs from him in being concerned (..) not with the use of 
pírico, cuya determinación conceptual se obtiene mediante el análisis de los modos de comportamiento de sus usuarios (contexto sociológico-pragmático).

Puede sostenerse, en resumen, que la tarea de formalización de la semántica ha llevado a Carnap a recorrer un camino de fundamentación progresiva hacia los estratos inferiores de la semiótica. Al querer encontrar la base conceptual ('verdad', 'significado') de una sintaxis lógica del lenguaje, procedió a postular la constitución de una semántica lógica (formalizable) y, finalmente, dentro de ésta, mediante la introducción de la tesis de intensionalidad, termina por trasladar el problema de la fundamentación del edificio lógico al campo pragmático:

There is an urgent need for a system of theoretical pragmatics, not only for psychology and linguistics, but also for analytic philosophy. ${ }^{75}$

Universidad Central de Venezuela

JuAn ANTONio Nuño

particular expressions but with classes of expressions; and whereas the propositions of the lexicographer are empirical, philosophical propositions, if they are true, are usually analytic". Por supuesto, que ahi reside todo el problema: en determinar su veracidad en ellas mismas o fuera de ellas. Quizás por todo ello Carnap termina pidiendo que quien lleve a cabo una encuesta lexicográfica ha de estar libre de "prejuicios filosóficos". Pero, acaso la obtención de "kinds of objects", en la determinación del 'dominio' de un predicado ¿no es una buena muestra de prejuicio universalizante?

75 Así termina el último de los "Studies in Semantics": Meaning and Necessity, Apéndice E: "On some concepts on Pragmatics". 